\title{
Epistemic and Political Goals for Education in a Troubled World
}

\author{
Claudia W. Ruitenberg \\ Department of Educational Studies, University of British Columbia
}

\section{INTRODUCTION}

Mike Smith and Harvey Siegel have analyzed the challenge of science students who understand certain scientific concepts and explanations but ultimately don't believe them. They argue that "an appropriate goal is for the student to recognize the scientific status of the theory in question, i.e., believe (in the non-religious sense) that the theory affords the best current scientific account of the relevant phenomena based on the available empirical evidence," but that belief in science as the best explanatory framework is not an appropriate goal. ${ }^{1}$ Belief in science, for instance when the student's religious belief leads them to reject science as an explanatory framework, would effectively require the student to substitute one belief for another: "This is the height of scientism - the position that all of a person's beliefs should be based on science."2

I have thought of Smith and Siegel's argument often when considering whether other beliefs are appropriate goals of public education. While I tend to agree with the argument as it pertains to science education, when considering public education in democratic societies more generally, things become more complicated. What if, for instance, the challenge involved students whose disbelief involves not scientific theories in the context of science education, but theories of democracy in the context of democratic education? Would I then still agree that knowledge and understanding, but not belief, are appropriate goals for education?

This is the question that came to mind as I read Mordechai Gordon's essay, "Critical Democratic Discourses, Post-Truth and Philosophy of Education." The issue is that I disagree with Gordon's framing of the problem as 
a problem exclusively, or even primarily, involving the truth-aspect of knowledge; rather, I will argue the problem ought to be framed first and foremost as one involving the belief-aspect of knowledge. While I agree that respect for evidence, cautious skepticism, and pragmatic open-mindedness are perfectly good educational goals, I will argue that what they miss is a belief in democracy, and the role of knowledge in it. Where Smith and Siegel reject scientism as an appropriate aspiration for education, I will argue that democratism is an appropriate aspiration. Moreover, the laudable epistemic abilities or virtues Gordon presents in his essay must be coupled with a belief in democracy to offer any hope.

\section{FOUCAULT'S QUESTIONS}

Gordon's critique of Michel Foucault's work is that it does not provide a solid epistemological basis for telling truth from falsehood and, moreover, that it does not provide a normative basis for seeking greater moral or political justice. This critique, however, misses the point of Foucault's interest, which is not in truth, and not even in knowledge itself, but rather in the subject's relation to knowledge or, put differently, in how different kinds of knowledge have, over time, shaped the subject differently. Foucault writes: "My objective ... has been to create a history of the different modes by which, in our culture, human beings are made subjects." ${ }^{33}$ In the current era, one of the key questions is how we have been made into the kinds of subjects who are so invested in our ability to judge for ourselves, to participate in knowledge-making, that we forget we are at the same time governed by this participation. If the task of the Enlightenment subject that Gordon invokes was to question external authority and to use its own understanding, the task of today's subject is not to be "governed like that and at that cost." We would do well to remember that the regime that peddled the myth of a "post-truth" society is the same regime that shut down and defunded numerous agencies that had been tasked with gathering scientific evidence. ${ }^{5}$

\section{SCIENTIFIC CONSENSUS AND POLTICAL CONSENSUS}

I would like to focus on a particular claim Gordon makes about 
Chantal Mouffe's work that further underscores the need for both a respect for truth and a commitment to democracy, and the impossibility of reducing the latter to the former. Gordon writes:

Mouffe's notion of agonistic pluralism has enabled us to better appreciate the centrality of conflict for the life of a democracy and that societies can become more democratic when they can promote adversarial conflicts rather than striving for those illusive rational agreements. But her concepts cannot help us persuade people to take facts and evidence seriously when a consensus is desperately needed like on the issue of climate change or on how to protect ourselves from Covid-19.

The problem with this passage is that it does not distinguish scientific (epistemic) consensus, from political consensus. Mouffe has argued that the focus on political consensus, certainly in the European Third Way politics of the early 2000s, is unhelpful, and that the democratic process means that there will ultimately be one political view that becomes hegemonic at a given time and will inevitably be met with opposition. This does not mean that she believes that scientific consensus is unhelpful. However, even if there is strong scientific consensus about a particular phenomenon, whether it is the relation between industrial animal agriculture and climate change, or the relation between the wearing of face masks and rates of COVID-19 transmission, the political decision about how to arrange the social order to respond to this evidence will still be the result of political struggle and will provoke further contestation.

I agree with Bruno Latour that the debate about "matters of fact," i.e., the epistemic debate, can be, and has been, used deliberately and strategically as a distraction from the political debate about responses to "matters of concern" such as the climate crisis. ${ }^{6}$ There is overwhelming scientific consensus about the severity and anthropogenic causes of the climate crisis. However, if people can be made to believe that they can and should use their ability to demand more evidence, be skeptical, and remain open-minded to counter-evidence as a way to delay action on a socially and ecologically 
critical issue, then it becomes more important to tell "friends from foes," as Latour would have it, than to tell truths from falsehoods. ${ }^{7}$

\section{COMMITMENT TO DEMOCRACY}

In 1939, the Jesuit priest William McGucken wrote an article sharply criticizing the popularity in educational circles of "democratism" as characterized by fellow Catholic Jacques Maritain. ${ }^{8}$ While I do not share McGucken's concern for the decline of respect for what he held to be the ultimate authority of God, nor his concern about Dewey's conception of democracy as being "from Moscow," I do believe he understood accurately that belief in democracy is a belief and commitment and that, as such, it can clash with other beliefs and commitments. So, I would like to reclaim the term "democratism," not to warn people against it, but to argue for it as the appropriate belief in, desire for, ${ }^{10}$ and commitment to democracy to be fostered in public schools.

I don't disagree with Gordon that public education must foster critical thinking, open-mindedness, and so forth, whether one understands these as virtues or not. However, "critical thinking" cannot consist only of the ability to question evidence but must also include the disposition-or, as Foucault would have it, "virtue"11_ of "not being governed like that and at that cost," 12 i.e., of questioning whose interests are being served by the encouragement to question the scientific evidence that supports measures against, for example, anthropogenic climate change and COVID-19 transmission. Finally, and not reducible to these epistemic goals, education must foster a commitment to democracy and its inevitable and ongoing struggle over power. Gordon argues that the three epistemic virtues of "respect for evidence, cautious skepticism, and pragmatic open-mindedness ... ought to become a focal point for educators." I argue that these three virtues should be taught only alongside the understanding that the insistence on certainty and complete scientific evidence serves a political purpose and is but another move in the modes of subjectification Foucault has documented. "When action modifies the very framework in which history is supposed to unfold, the idea of distant, disinterested facts becomes less relevant than that of highly 
disputed matters of concern." 13

1 Mike Smith and Harvey Siegel, "Knowing, Believing, and Understanding: What Goals for Science Education?" Science \& Education 13 (2004): 553-582, 565.

2 Smith and Siegel, "Knowing, Believing, and Understanding," 568.

3 Michel Foucault, “The Subject and Power," Critical Inquiry 8 (1982): 777 $795,777$.

4 Michel Foucault, "What is Critique?" in The Politics of Truth (Los Angeles: Semiotext(e), 2007), 45.

5 See, for example, Jeff Tollefson, "How Trump Damaged Science - And Why It Could Take Decades to Recover," Nature, 7 October 2020, https:// www.nature.com/articles/d41586-020-02800-9; Brad Plumer and Coral Davenport, "Science Under Attack: How Trump Is Sidelining Researchers and Their Work," The New York Times, 29 December 2019, https://www.nytimes. com/2019/12/28/climate/trump-administration-war-on-science.html.

6 Bruno Latour, "Why Has Critique Run out of Steam? From Matters of Fact to Matters of Concern," Critical Inquiry 30 (2004): 225-248.

7 Bruno Latour, "Telling Friends from Foes in the Time of the Anthropocene," in The Anthropocene and the Global Environmental Crisis: Rethinking Modernity in a New Epoch, eds. Clive Hamilton, François Gemenne and Christophe Bonneuil (Abingdon, UK: Routledge, 2015), 145-155.

8 William J. McGucken, "Democracy or Democratism in Education," Thought 14, no. 2 (1939): 178-182.

9 McGucken, "Democracy or Democratism in Education," 182.

10 Gert Biesta, “'The Ignorant Citizen: Mouffe, Rancière, and the Subject of Democratic Education," Studies in Philosophy and Education 30 (2011): 141-153.

11 Foucault, "What is Critique?" 43. 
12 Foucault, 45.

13 Latour, "Telling Friends from Foes," 149. 